\title{
Dependence of anatomical structure features on morphological form of branching of grass shoots
}

\author{
LEONTYNA OLSZEWSKA ${ }^{1}$ and MARIA WIELICKA ${ }^{2}$
}

\author{
${ }^{1}$ Institute for Land Reclamation and Grassland Farming, Al. Ossolińskich 12, 85-093 Bydgoszcz, \\ Poland \\ ${ }^{2}$ Agricultural Institute Technological-Agricultural University, ul. Bernardyńska 6, 85-029 Bydgoszcz, \\ Poland
}

$\langle$ Received: October 11, 1982〉

\begin{abstract}
The occurrence of different shoot forms in Dactylis glomerata L., Festuca arundinacea Schreb., Holcus lanatus L., Avena fatua L. and other grass species was observed in investigations on vegetative reproduction modes deviating from normal. The relationship between the morphological and anatomical structure of these shoots, depends on the grass species as well as on ecological and biotic factors. The anatomical structure of elongated vegetative tillers and pseudostolons as well as underground rooting stems regrowing in the soil approximates that of stolons in Poa trivialis L. Branching generative shoots show the same arrangement of tissues as that encountered in non-branching ones. Shoots with such a structure are resistant to bending and, therefore, their contact with the soil and rooting of aerial tillers meet, as a rule, with difficulties. All kinds of parental branching shoots under study, irrespective of whether they developed above or in the soil, are usually shortlived, provided with sheaths and leaf blades, similarly as stolons. It was found that in many grass species different tillering forms occur generally in vegetative reproduction what would require a definition and unification of names of such differentiated shoots.
\end{abstract}

\section{INTRODUCTION}

The mode of grass tillering is not indifferent for the structure of the meadow sward and this in turn affects the yield and longevity of the meadow. In dependence on the mode of management grasses adapt themselves and reproduce vegetatively. The main advantage of such reproduction is the high competitive ability of the new shoots, owing to their connection with the parent plant, as compared with the weak plants from seeds which are overrun in the thick sward by old grass specimens.

The longevity of the meadow sward is ensured when the number of newly formed shoots is greater than that of the dying ones. Shoots growing from rhizomes and tillering nodes at the ground ensure the highest longevity and yield (B e 1 u č e n k o, 1977). 
The adaptation ability of grasses to ecological and biotic conditions is manifested among other ways by the shift of the sites of new tiller formation (E v a n s, 1927; W e b e r, 1929; B a k e r, 1956; K y d d, 1966; O ls z e w s k a, 1967; J a c k s o n, 1974; S i m o n s et al., 1974; H a r r is et al., 1979; M i nde r hou d, 1978; 1980a, b; O $1 \mathrm{~s} \mathrm{zew} \mathrm{s} \mathrm{k} \mathrm{a} \mathrm{and}$ W i e l i ck a, 1978a, b; 1979; 1980; 1981a, b).

An advantageous form for densifying the sward is in tuft grasses reproduction by means of runners or underground rooting stems.

Least persistent are lateral shoots growing from upper lying intercalary meristems on erect generative stems, if no conditions occur enabling contact of the parent shoots with the soil ( $\mathrm{M}$ i n d e r h o u d, 1978; 1980b; O 1 s z e ws k a and W i e $1 \mathrm{i} \mathrm{ck} \mathrm{a,} \mathrm{1980;1981b;} \mathrm{H}$ a y e s, 1971). It should be mentioned that raised aerial tillering has an inhibitory effect on tillering from the basal nodes, thus causing a thinning of the sward.

Morphological changes in grass shoots are usually accompanied by anatomical ones as remarked by $M$ ü 11 e $r-S t o l l$ (1952) when investigating runners of Phragmites communis as well as $\mathrm{Ols} \mathrm{ze} \mathrm{w} \mathrm{s} \mathrm{k} \mathrm{a} \mathrm{and} \mathrm{W}$ i e$1 \mathrm{i} \mathrm{c} \mathrm{k} \mathrm{a}(1978 \mathrm{a}, \mathrm{b} ; 1981 \mathrm{a}, \mathrm{b})$ in studies on a number of cultivated and wild growing grasses.

The purpose of the present study was to demonstrate in what consists the connection between the morphological and anatomical structure of branching parent grass shoots. This may elucidate the mechanism of adaptation of grasses to variable environmental conditions and management. A knowledge of this adaptation may be utilized for the formation of a persistent structure of the meadow sward.

\section{MATERIALS AND METHODS}

In earlier papers the authors described the conditions under which grass species with abnormal tillering were collected (Olszewska and Wielicka $1978 \mathrm{a}, \mathrm{b} ; 1979 ; 1980 ; 1981 \mathrm{a}, \mathrm{b})$. The observations of the collected specimens are documented by pho'eraphs and descriptions of the shoot morphology.

For anatomical examination of the parent shoots cross sections through the internodes were prepared over which the lateral shoots were growing from the nearest intercalary meristem.

The plants were dehydrated with a rising alcohol gradient up to 75 per cent. Sections $40 \mu \mathrm{m}$ thick were cut on a sliding microtome. Arrangement of parenchymatous and vascular tissues was then analysed in shoots of the selected grass species and some measurements were performed by way of example. For illustration microphotographs and schematic drawings of shoot cross sections are included. 


\section{RESULTS AND DISCUSSION}

Aerial tillers arise on erect or parent running ones. In some species various forms of aerial tillers may be found (Figs. 1, 2, 3).

On the example of Dactylis glomerata branching of generative intact stems or those decapitated from higher situated nodes (Fig. 1) and of pseudostolons may be observed (Fig. 2). The latter were detected hidden under the profuse foliation. On the erect generative stem "anchoring" roots are visible growing from the base of the aerial tillers (O l s z e w s k a and W i e 1 i c k a 1980;1981b). In a thick profusely foliated tuft of Festuca arundinacea erect vegetative and creeping tillers with elongated internodes, and lateral branchings (Fig. 3) are seen. These specimens were collected in November 1981 on fallow land which had been strongly manured in spring.

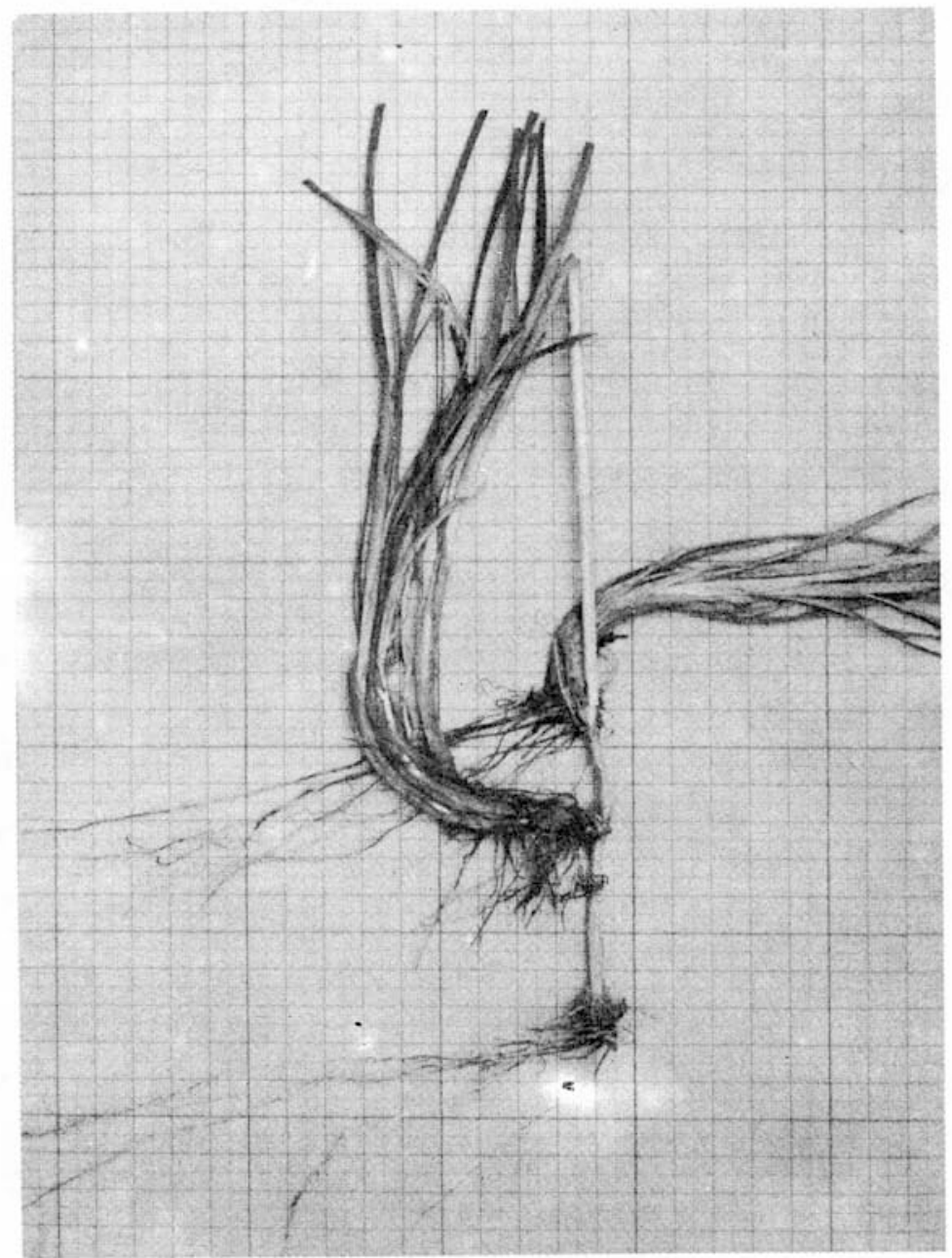

Fig. 1. Branching generative stem of Dactylis glomerata L. 
The elongation of internodes of vegetative stems may have been due to shading. Other authors observed internode elongation when the tillering nodes were covered with sand, soil or straw or shaded by dense foliage ( $\mathrm{E} \vee \mathrm{a} \mathrm{n}$, 1927; von Horn, 1936; K wart a and M á la n k ow s a, 1964; Olszewska, 1967; Simons et al., 1974; Harris et al., 1979; M inderhoud, 1978; 1980b; O Iszewska and Wielicka, 1978a, b; 1979; 1980; 1981a, b).

Hol mes et al. (1960), however, noted in wheat either shortening or elongation of internodes in dependence on the development phase of the plants at the time of shading. Elongation of shoots of Festuca arundinacea may have been caused among others by abundant nitrogen fertilization. However, an abundant nitrogen supply may have different effects as observed by D a v i e s (1980) in studies on Lolium perenne and Dactylis glomerata. There is a marked tendency in some grass species and varieties to aerial tillering, irrespective of environmental factors (C o o per, 1951; M in d e r h o u d, 1978; 1980b; H a r r is et al., 1979; O l s z e w s k a and W i e l i c k a, 1980; 1981b).

P o r t e r (1958) observed in Festuca arundinacea formation in the soil of elongated stems in the second and third year after setting of the plantation. He concludes therefrom that selection for stolon-forming genotypes in this tuft grass may be useful on eroded areas. H a r r is et al. (1979) and $\mathrm{M}$ i n d e r h o u d (1980b) stress the favourable influence of the presence of

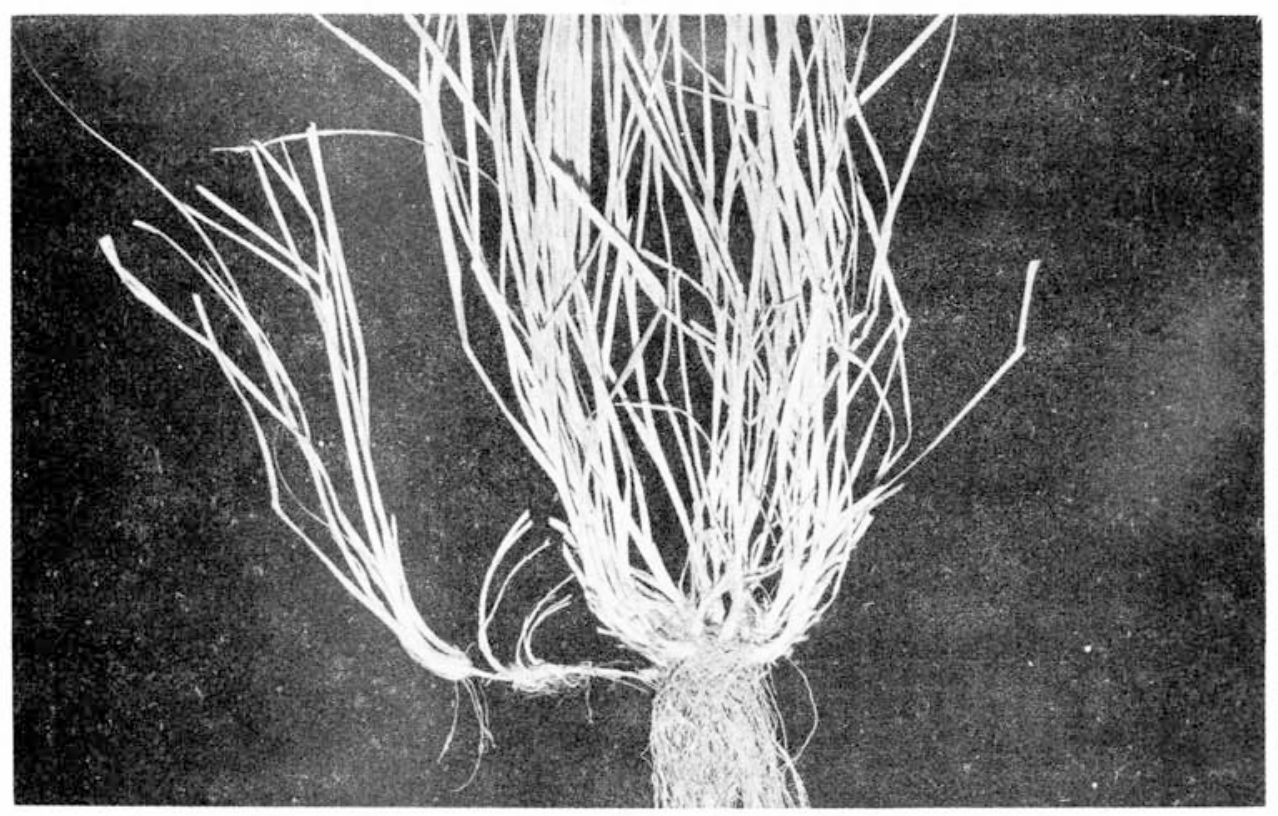

Fig. 2. Pseudostolon of Dactylis glomerata L. 


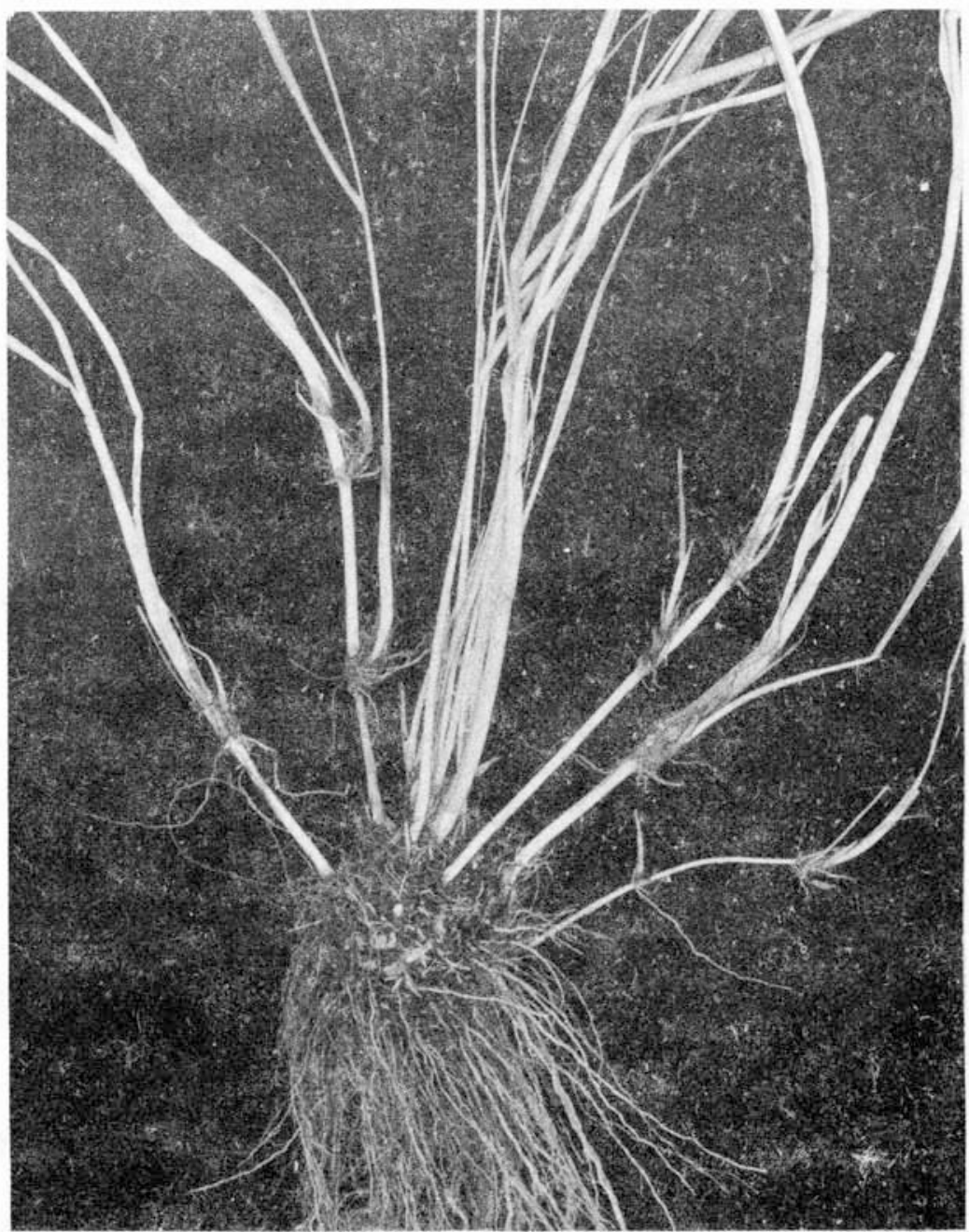

Fig. 3. Branching vegetative tillers with elongated internodes of Festuca arundinacea Schreb.

Lolium perenne genotypes, forming above and underground pseudostolons, on the longevity of the sward.

Pseudostolons may also arise under the influence of management. The pseudostolons of Holcus lanatus (Fig. 4) began to form in 1980 in June on the boundary of a tuft the central shoots of which were repeatedly cut off in the course of vegetation, thus they arose under conditions of favourable illumination. W a t t (1978) similarly obtained pseudostolons in Holcus lanatus and he ascribed it to the adaptation of the form of vegetative reproduction to the mode of utilization. M ü 11 e r-S t o 11 (1952) noted formation of creeping stems in Phragmites communis growing in open communities and he interprets this as due to the action of wind and grazing of cattle. 
For further observations the pseudostolons of Holcus lanatus were labelled in the autumn of the first year. The shoots overwintered well and were green on their whole length. In the next year at the end of May heading began in the parent tuft as well as in the rooted shoots at the end of the parent vegetative stem which was $33 \mathrm{~cm}$ long. The internodes of the parent stem died at the beginning of autumn, whereas the tufts of lateral shoots were rooted and overwintered.

According to the observations of $\mathrm{M} \mathrm{inde} \mathrm{rhoud}$ (1980) it also appeared that roots grow from the intercalary meristems of elongated or running vegetative tillers and from the base of lateral ones. In the branching generative stem root growth was not observed from the intercalary meristems themselves, only from the base of the lateral shoots (M i n d e r h o u d, 1980; O lszewska and W i e li ck a, 1981b).

In the annual grass Avena fatua (Fig. 5) rooting stems grew from the tillering nodes covered with soil during ridging of potatoes, similarly as they do in perennial grasses. It was also found that aerial tillers form on Avena fatua generative stems. In contrast to perennial grasses the lateral rooting stems of Avena fatua were shortlived and did not overwinter.

It results from the foregoing that the pseudostolons of tuft grasses resemble morphologically the stolons of Poa trivialis (Fig. 6). In the pseudostolons and in

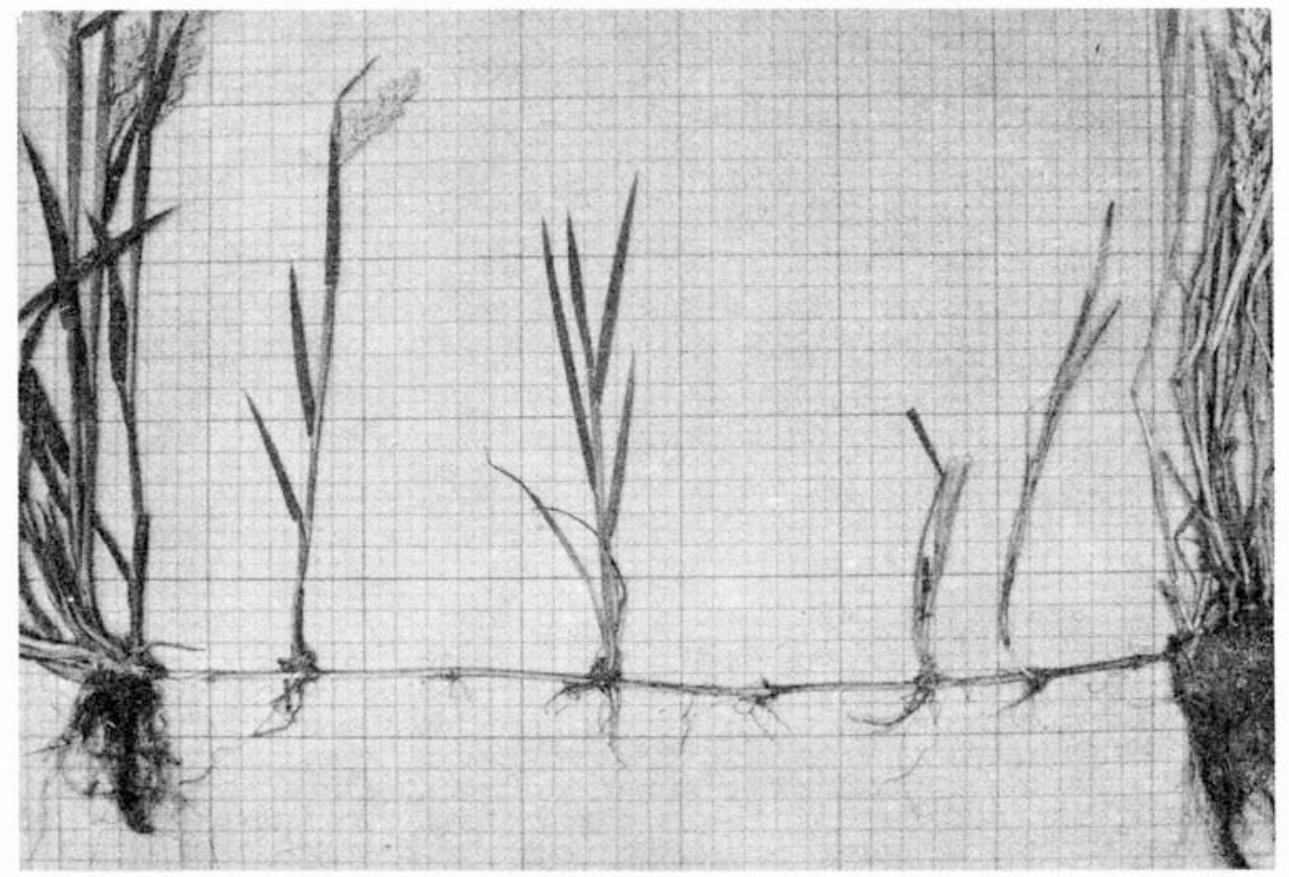

Fig. 4. Pseudostolon of Holcus lanatus L. 


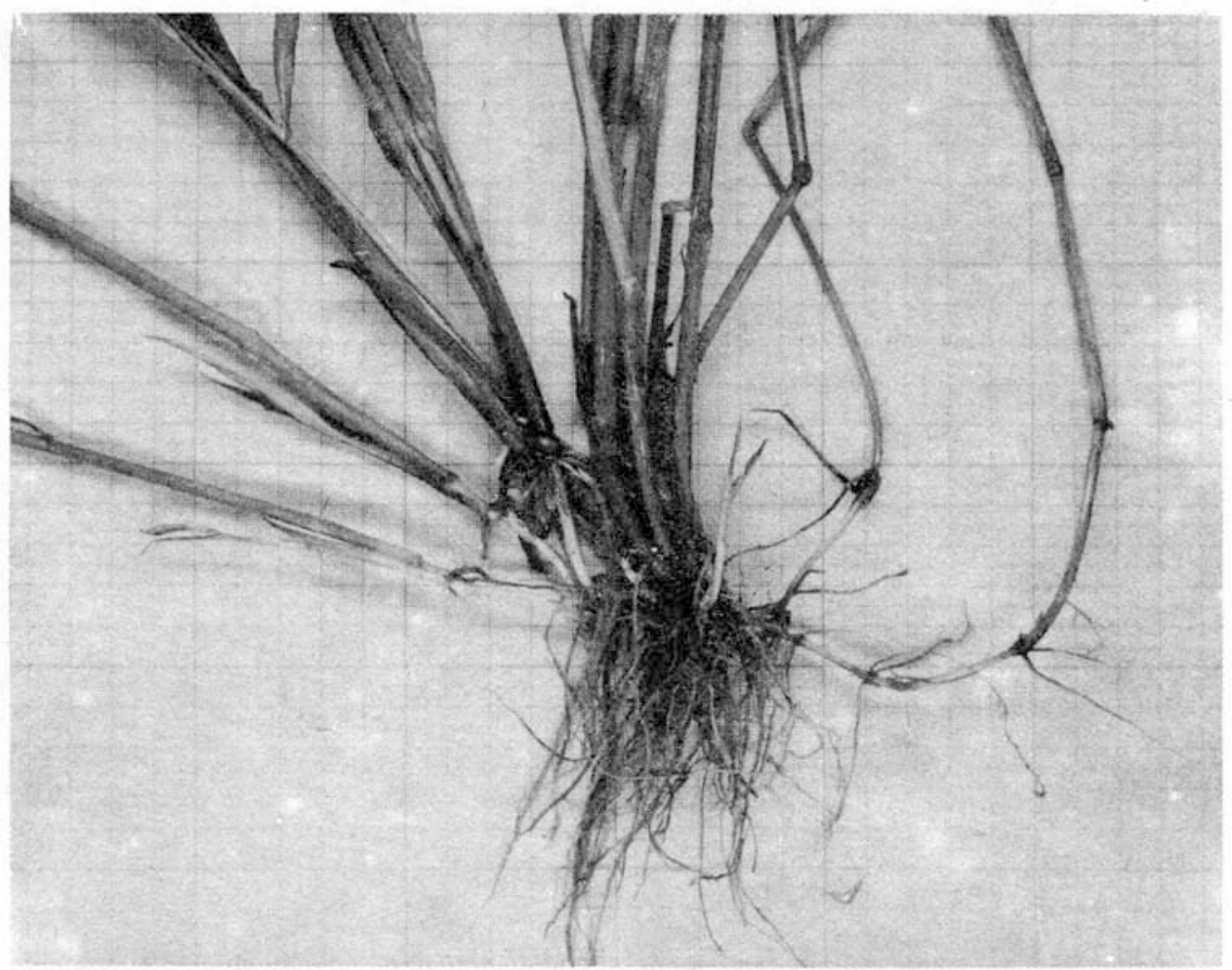

Fig. 5. Underground rooting stem of Avena fatua L.

rooting stems under a soil cover the presence of sheaths and leaf blades is observed. Under the soil cover the sheaths and leaf blades decompose and after a time there only remain fibrous residues $(\mathrm{O} 1 \mathrm{~s} \mathrm{z} \mathrm{e} \mathrm{w} \mathrm{s} \mathrm{k} \mathrm{a} \mathrm{and} \mathrm{W}$ i e $1 \mathrm{i} \mathrm{c} \mathrm{ka}$, 1978b; H a r r i s et al., 1979). Lateral shoots on runners do not die, but they root in the soil and tiller, forming shoot agglomerations, whereas the internodes of the parent shoot die. As regards the rooting stems growing in the soil, their internodes die at warious times in dependence on the grass species $(\mathrm{O} 1 \mathrm{~s} \mathrm{z}$ e w$\mathrm{s} \mathrm{k} \mathrm{a}$ and $\mathrm{W}$ i e $1 \mathrm{i} \mathrm{c} \mathrm{k} \mathrm{a,} \mathrm{1979;} \mathrm{1981a).} \mathrm{The} \mathrm{aerial} \mathrm{tillers} \mathrm{on} \mathrm{generative} \mathrm{stems}$ die if the parent stem does not fall to the ground, and usually the rigidity of the stem prevents this (O $1 \mathrm{~s} \mathrm{z} \mathrm{e} \mathrm{w} \mathrm{s} \mathrm{k} \mathrm{a} \mathrm{and} \mathrm{W} \mathrm{i} \mathrm{e} \mathrm{l} \mathrm{i} \mathrm{c} \mathrm{k} \mathrm{a,} \mathrm{1980;} \mathrm{1981b).} \mathrm{The}$ aerial tillers on erect stems are exposed to freezing and extirpation by grazing animals or by mowing machines (M i n d e r h o u d, 1978; H a y e s, 1971; S i m o n s et al., 1974).

Trampling by grazing animals, covering of the meadow surface with sand, compost or manure may favour rooting of the lateral branchings, this affecting favourably the density of the sward (M i t c h e 11, 1956; O I s z e w s k a, 1967; Olszewska and Wielicka, 1979; M inderhoud, 1980b). 


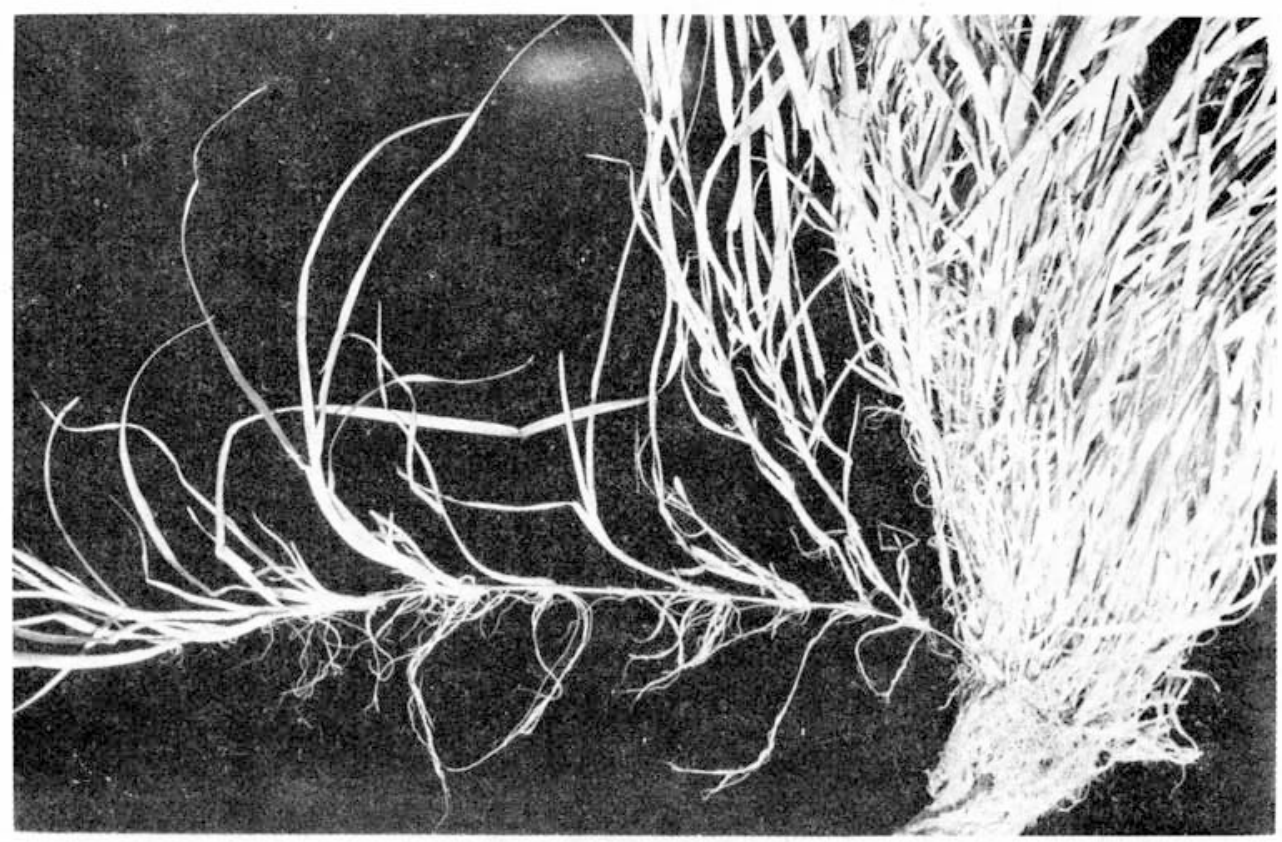

Fig. 6. Stolon of Poa trivialis L.

Anatomical investigations demonstrated that the arrangement of the tissues in the pseudostolons and elongated vegetative tillers is similar to that in the stolon of Poa trivialis (Plate I: P- $\mathrm{n}_{5}$, II). In the fifth internode from the base of the parent tuft of Poa trivialis (Plate I: P- $\mathrm{n}_{5}$ ) the stem diameter is $1150 \mu \mathrm{m}$. Under the epidermis there lies parenchyma of $165 \mu \mathrm{m}$ thickness consisting of six cell layers. Closer to the centre of the stem there is a sclerenchyma layer about $84 \mu \mathrm{m}$ thick with a small air canal in the middle (not visible on the microphotograph). In Festuca arundinacea (Plate II: F- $\mathrm{n}_{2}$ ) parenchyma is present under the epidermis, consisting of six cell layers in the second elongated internode of the erect vegetative tiller. The parenchyma is thicker than in Poa trivialis, amounting to $270 \mu \mathrm{m}$.

In pseudostolons of Holcus lanatus (Plate I: $\mathrm{H}-\mathrm{n}_{7}$ ) in the seventh internode and in Dactylis glomerata (Plate II: D- $\mathrm{n}_{2}$ ) in the second there are five parenchyma cell layers of 180 and $195 \mu \mathrm{m}$ thickness, respectively. Sclerenchyma underlies the parenchyma.

In contrast to vegetative tillers there appears in generative stems in the second above ground internode of Holcus lanatus (Plate II: H-2) and in Dactylis glomerata (Plate II: D-2) under the epidermis a sclerenchyma layer with vascular bundles and islets of chlorenchyma and under this layer closer to the centre there is parenchyma. This structure is specific to generative stems of these grasses giving them resistance to bending. 


\section{Pla te I}
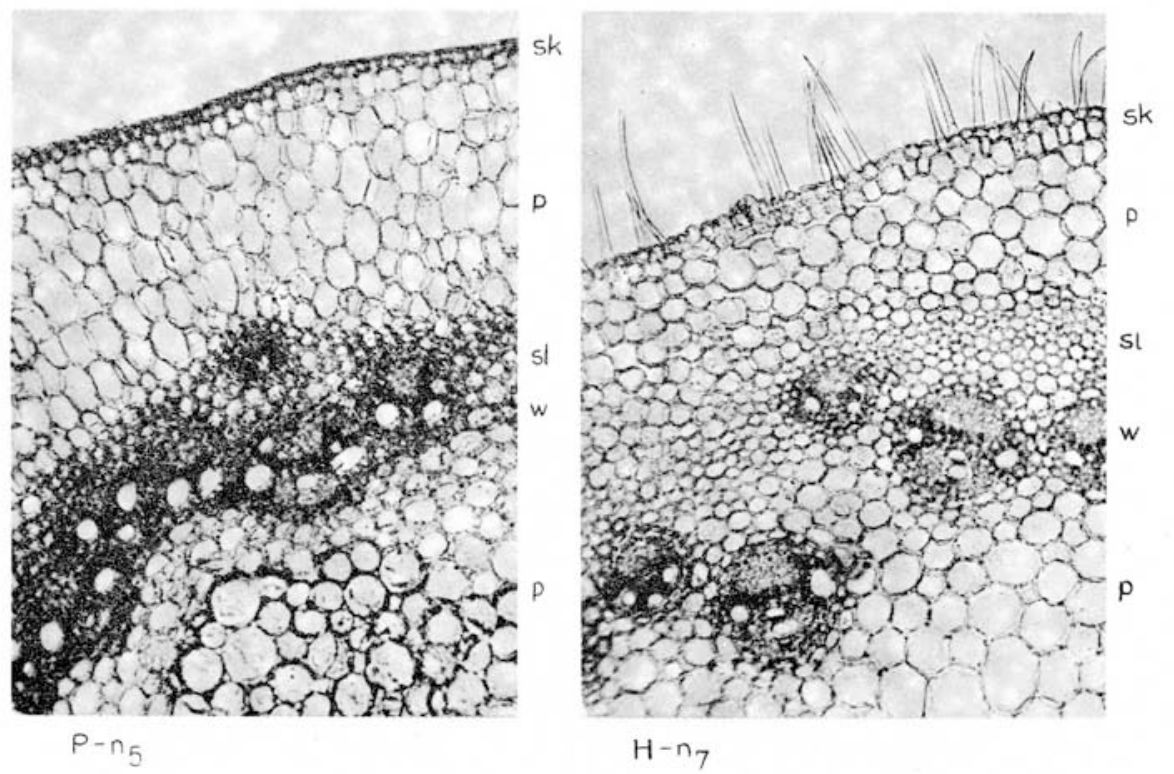

Cross sections of stems; $\mathrm{P}-\mathrm{n}_{5}-$ Microphotograph of fifth internode from the stolon of Poa trivialis L.; $\mathrm{H}-\mathrm{n}_{7}$ - Microphotograph of cross section of seventh internode from the pseudostolon of Holcus lanatus L. $\left\langle\mathrm{P}-\mathrm{n}_{5}-\times 106 ; \mathrm{H}-\mathrm{n}_{7}-\times 130\right\rangle$. Notations: $\mathrm{sk}-$ epidermis, $\mathrm{sl}-$ sclerenchyma, $\mathrm{w}-$ vascular bundles, $\mathrm{p}-$ parenchyma 

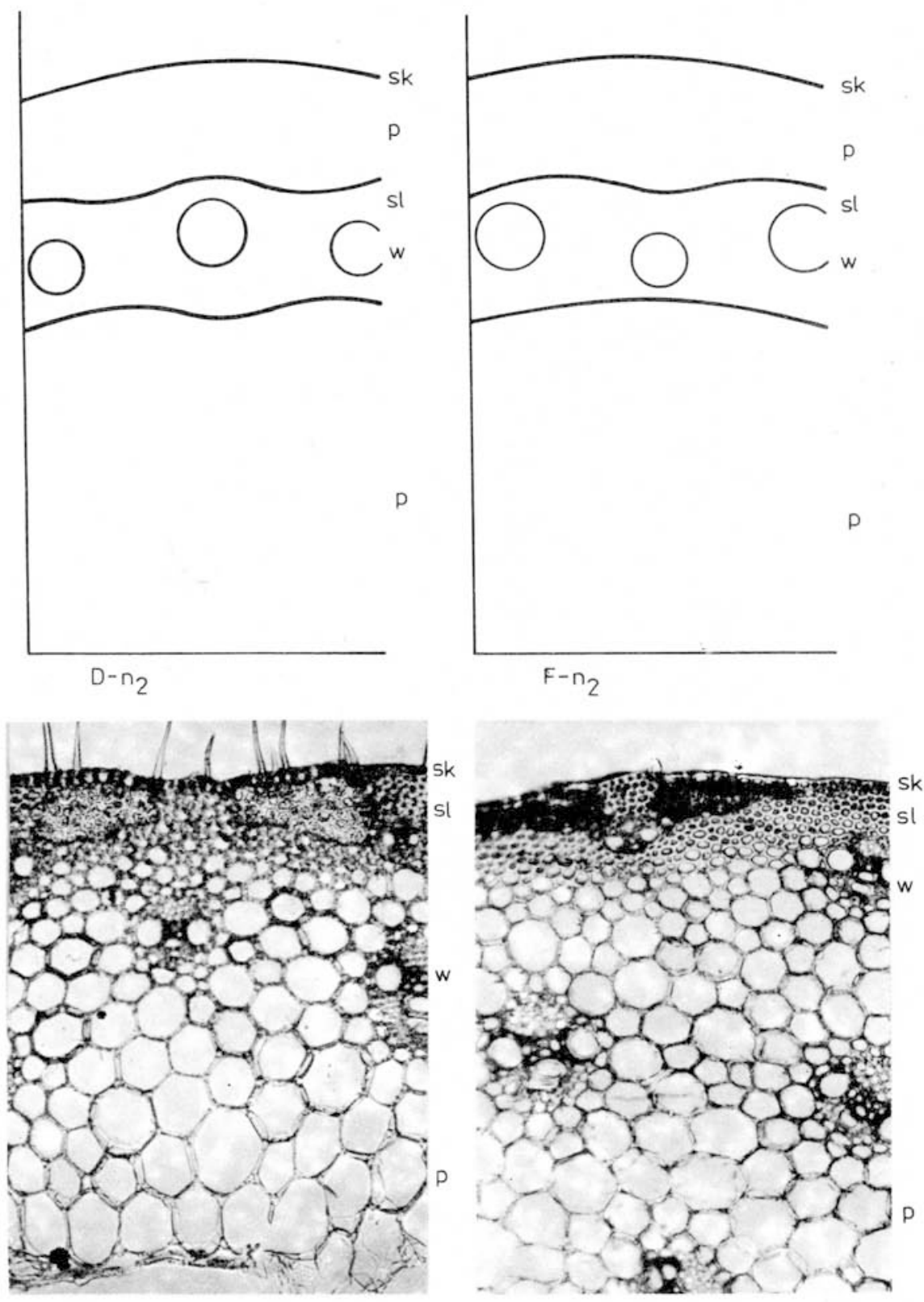

$\mathrm{H}-2$

$\mathrm{D}-2$

Cross sections of stems: D- $\mathrm{n}_{2}$ - Diagram of cross section of second internode from the pseudostolon of Dactylis glomerata L.; F- $\mathrm{n}_{2}$ - Diagram of cross section of second internode from elongated vegetative tiller of Festuca arundinacea Schreb.; H-2 - Microphotograph of cross section of second internode from branching generative stem of Holcus lanatus L.; D-2 - Microphotograph of cross section of second internode form branching generative stem of Dactylis glomerata L. $\langle\mathrm{H}-2-\times 150, \mathrm{D}-2-\times 150\rangle$ For notations - see Plate I 
In the examined grass species differences were also found in the thickness of the sclerenchyma cell walls in dependence on the kind of tillers (Table 1). In pseudostolons and stolons the walls are thinner, not exceeding $2 \mu \mathrm{m}$, whereas in the branched generative stems the cell wall thickness is in dependence on the species 2.7 to $4.6 \mu \mathrm{m}$.

Ta b le 1

Thickness of sclerenchyma cell-walls dependent on morphology of branching tillers in some grass species

\begin{tabular}{|c|c|c|}
\hline $\begin{array}{l}\text { Species } \\
\text { Tiller }\end{array}$ & $\begin{array}{l}\text { Successive internode } \\
\text { from the shoot } \\
\text { base }\end{array}$ & Thickness $\mu \mathrm{m}$ \\
\hline $\begin{array}{l}\text { Pseudostolon } \\
\text { Holcus lanatus L. }\end{array}$ & $1-7$ & 1.6 \\
\hline $\begin{array}{l}\text { Stolon } \\
\text { Poa trivialis L. } \\
\text { Agrostis, stolonifera L. }\end{array}$ & $\begin{array}{l}1-5 \\
\text { All }\end{array}$ & $\begin{array}{l}1.4 \\
1.3\end{array}$ \\
\hline $\begin{array}{l}\text { Branching generative stems } \\
\text { Lolium multiflorum Lam. } \\
\text { Phleum pratense L. } \\
\text { Bromus unioloides H.B.K. } \\
\text { Dactylis glomerata L. } \\
\text { Arrhenatherum elatius (L.) } \\
\text { P.B. } \\
\text { Holcus lanatus L. }\end{array}$ & $\begin{array}{l}2 \\
2 \\
2 \\
2 \\
2 \\
2\end{array}$ & $\begin{array}{c}2.7 \\
2.7 \\
3.2 \\
3.8 \\
4.6 \\
2.7\end{array}$ \\
\hline
\end{tabular}

It results from the above considerations that pseudostolons or vegetative tillers with elongated internodes have a similar tissue arrangement as that in stolons. This facilitates their contact with the soil, making possible rooting of subsidiary tillers. Then the parent stems play the role of stolons, increasing the density of the meadow sward owing to increased competition ability.

In general branched generative stems are resistant to bending, therefore, the lateral branches usually die with the parent stem.

The genetic properties of the plants influence the morphology and anatomy of the branching shoots and so do the habitat conditions and biotic factors.

In view of the property of grasses which respond to various factors by transfer of the site of new shoot formation when tillering occurs under conditions differing from normal, the terminology of the aerial and parent shoots should be normalized. M i n d e $\mathrm{r} \mathrm{h}$ o u d (1980) suggests that vegetative stems running on the surface are stolons (German: Stolon), or pseudostolons (German: Pseudostolon). M i n d e $\mathrm{r} \mathrm{h}$ o u d (1980), however, referring to the papers by M i tchell (1956), O ls zew ska and Wielick a (1978b) and $\mathrm{H}$ a $\mathrm{r} \mathrm{r}$ i s et al.(1979) affirms that the elongated stems of grasses growing under the ground have so far not been strictly defined. They resemble stolons buried in 
the soil. H a r r i s et al. (1979) classify together stolons, runners and rooting stems growing in the soil, the duration of which is short as compared with that of true rhizomes. O l s z e w s k a and W i e l i c k a $(1978 \mathrm{~b} ; 1979 ; 1981 \mathrm{a})$ called attention to the relatively early dying back of the internodes of elongated stems arising at tillering nodes of grasses buried in the soil.

A distinguishing feature is also the presence in stolons of sheaths and leaf blades which are absent in the rhizomes (O $1 \mathrm{~s} \mathrm{z} \mathrm{e} \mathrm{w} \mathrm{s} \mathrm{k} \mathrm{a} \mathrm{and} \mathrm{W} \mathrm{i} \mathrm{e} 1 \mathrm{i} \mathrm{c} \mathrm{k} \mathrm{a,}$ $1978 \mathrm{~b} ; 1979 ; 1981 \mathrm{a} ; \mathrm{H}$ a r r i s et al., 1979). In rooting tillers buried in the soil the leaf blades and sheaths are usually in a state of decomposition, their presence may, however, be ascertained in the form of fibrous remains. The main difference is the geotropic reaction of the rooting stems $(\mathrm{O} 1 \mathrm{~s} \mathrm{z}$ e w s k a and $\mathrm{W}$ i e$1 \mathrm{ick} \mathrm{a,} \mathrm{1978a).} \mathrm{The} \mathrm{same} \mathrm{physiological} \mathrm{process} \mathrm{is} \mathrm{the} \mathrm{base} \mathrm{for} \mathrm{stolons}$ formation, irrespective of whether they are on the surface or under it. The question remains open, however, to which group the aerial tillering of generative stems should be classified (H a r $r$ i s et al., 1979).

\section{CONCLUSIONS}

1. Branching runners and vegetative tillers with elongated internodes have a similar arrangement of tissues as stolons.

2. Branching generative stems exhibit a tissue pattern specific for normal generative stems.

3. In dependence on the morphology and anatomy of branching shoots there is a greater or smaller possibility of their contact with the soil, what would make possible rooting and tillering of lateral shoots.

4. In view of the ability of transfer of the site of new tillers formation' in vegetative reproduction of most grasses, it is indispensable to establish strict definitions and a uniform terminology for the particular kinds of shoots.

\section{REFERENCES}

B a k e r H. K., 1956. Note on the influence of previous management on the death of perennial ryegrass during winter. Journ. Brit. Grassld. Soc. 11: 235-237.

B e 1 u z e n k o I. S., 1977. Osobennosti otrastaniya panikoidnykh i eragrostoidnykh mnogoletnikov. Proc. XIIIth Intern. Grassld. Congr., Sec. 1-2, Leipzig 43-49.

C o o p e r J. P., 1951. Studies on growth and development in Lolium. II. Pattern of bud development of the shoot apex and its ecological significance. J. Ecol. Camb. 39: 228-270.

D a vi es I. 1980. Developmental characteristics of grass varieties in relation to their herbage production. J. Agric. Sci. Camb. 94: 125-136.

Ev a n s M. W., 1927. The life history of timothy. U. S. D. A., Dep. Bull. No. 1450, Washington. Harris W., P a nde y K. K., Gray Y.S., C o u c h m a n P. K., 1979. Observations on the spread of perennial ryegrass by stolons in a lawn. N. Z. J. Agric. Res. 22: 61-68.

$\mathrm{H}$ a y e s P., 1971. Stoloniferous perennial ryegrass 〈Lolium perenne〉 in Northern Ireland paddocks. Rec. Agric. Res., Min. of Agric. for Northern Ireland. 19: 63-64. 
H o l m e s N. D., La r s o n R. I., P e terson L. K., M a c D o n a ld M. D., 1960. Influence of periodic shading on the length and solidness of the internodes of rescue wheat. Can. J. Plant Sci. 40: 183-187.

H o r n A. von, 1936. Die Rasenschmiele. Diss. Berlin.

J a c k s o n D. K., 1974. Some aspects of production and persistency in relation to height of defoliation of Lolium perenne 〈var. S23〉, Proc. XIIth Intern. Grassld. Congr., Moscow, pp. 202-214.

K w a r t a C., M a śl a n k ow s k a L., 1964. Regeneracja śmiałka darniowego Deschampsia caespitosa 〈L.〉 P. B. na łące torfowej zaoranej. Zesz. Nauk. WSR Szczec. 17: 69-83.

K y d d D. D., 1966. The effect of intensive sheep stocking over a five-year period on the development and production of the sward. Journ. Brit. Grassld. Soc. 21: 284-297.

M i n d e r h o u d J. W., 1978. Pseudostolons and aerial tillers: morphological phenomena of Lolium perenne L. Europ. Grassld. Fed., 7th Gen. Meet. Gent 〈Belgium〉.

M i n d e r h o u d J. W., 1980a. Tillering and persistency in Lolium perenne L. Proc. Third Intern. Turfgrass Res. Conf. München, 1977.

M i n d e r h o u d J. W., 1980b. Triebformen bei Lolium perenne L. Rasen-Turf-Gazon 2: 35-41.

$\mathrm{M}$ i t c h e $11 \mathrm{~K}$. J., 1956. The influence of light and temperature on the growth of pasture species. Proc. VIIth Intern. Grassld. Congr. New Zealand 58-69.

M ü 11 e r-S t o 11 W. R., 1952. Uber die Entstehung von kriechenden Schilfsprossen auf Dünensand. Biol. Zentralblatt. 71: 618-626.

O ls z e w s k a L., 1967. Wpływ piaskowania na zmiany składu botanicznego i plony ląki opanowanej przez trzęślicę modrą Molinia coerulea 〈L.> Moench. Rocz. Nauk Rol. Ser. F, 76: 681-707.

O ls z e w s k a L., W i e l i c k a M., 1978a. Regrowth ability of the tufted grasses, covered with soil. Europ. Grassld. Fed., 7th Gen. Meet. Gent 〈Belgium〉.

O 1 s z e w s k a L., W i e l i c k a M., 1978b. Zdolność odrastania traw kępowych po przykryciu ich ziemią. Acta Agrobot. 31: 95-106.

O l s z e w s k a L., W i e l i c k a M., 1979. Zdolność odrastania traw kępowych po przykryciu ziemią ich węzłów krzewienia. Inf. IMUZ, dod. Wiad. Melior. 5: 151-152.

O l s z e w s k a L., W i e 1 i c k a M., 1980. Niektóre obserwacje nad rozkrzewianiem się traw. Nowe Rol. 13: 15-17.

O l s z e w s k a L., W i e l i c k a M., 1981a. Wpływ częściowego przykrycia ziemią na morfologię i anatomię odrastających pędów kępowych traw. Acta Agrobot. 34: 45-52.

O 1 s z e w s k a L., W i e 1 i c k a M., 1981b. Rozgałęzianie się pędów nadziemnych u niek tórych traw. Acta Agrobot. 34: 53-67.

P o r t e r Jr. H. L., 1958. Rhizomes in tall fescue. Agr. Journ. 50: 493-494.

$\mathrm{S}$ i m o n s R. G., Davi es A., T r o u g h t o n A., 1974. The effect of cutting height and mulching on aerial tillering in two contrasting genotypes of perennial ryegrass. J. Agric. Sci. Camb. 83: 267-273.

W a $t$ t T. A., 1978. Yorkshire fog $\langle$ Holcus lanatus L. $\rangle$ a review and some recent research. Journal of the Sports Turf Research Inst. 54: 15-22.

W e b e $r$ C. A., 1929. Ausläufertreibendes deutsches Weidelgras. Mitt. Deutsch. Landw. Gesellsch. 41: 913-916.

\section{ZALEŻNOŚĆ CECH BUDOWY ANATOMICZNEJ OD MORFOLOGICZNEJ FORMY ROZGAEĘZIAJĄCYCH SIĘ PĘDÓW TRAW}

St reszczenie

Prowadząc badania sposobów wegetatywnego rozmnażania u Dactylis glomerata L., Festuca arundinacea Schreb., Holcus lanatus L., Avena fatua L. i u innych traw, zaobserwowano występowa- 
nie różnych form pędów. Ustalono, że związek między budową morfologiczną i anatomiczną tych pędów zależy od gatunku trawy i od czynników ekologicznych oraz biotycznych.

Nadziemne pędy płożące się i wegetatywne wydłużone, jak też ukorzenione pędy odrastające w ziemi, mają budowę anatomiczną zbliżoną do budowy rozłogów nadziemnych u Poa trivialis $\mathbf{L}$.

Rozgałęziające się pędy generatywne mają układ tkanek taki sam, jaki spotyka się u nierozgałęziających się pędów. Tak zbudowany pęd na ogól nie ulega zginaniu, stąd zetknięcie się z ziemią powietrznych pędów i zakorzenienie się napotyka przeszkody.

Wszystkie badane rodzaje macierzystych, wydłużonych pędów, niezależnie od tego czy powstały nad ziemią czy w ziemi, są zazwyczaj krótkotrwałe, zaopatrzone w pochwy i blaszki liściowe, podobnie jak rozłogi nadziemne.

Stwierdzono, że u wielu gatunków traw rozmnażających się wegetatywnie występują dość powszechnie różne formy krzewienia, co wymaga zdefiniowania i ujednolicenia nazw tych zróżnicowanych pędów. 